\title{
"Hooking Up" and Hanging Out: Casual Sexual Behavior Among Adolescents and Young Adults Today ${ }^{1}$
}

Christy Daniel and Kate Fogarty ${ }^{2}$

\section{Current Trends in Adolescent and Young Adults' Sexuality}

Adolescents' and young adults' sexual attitudes and behaviors have gotten a lot of attention from researchers, the media, and policy makers in the past decade. Trends show a decline in traditional forms of dating, suggesting that casual sexual interaction, often referred to as "hooking up," has become an alternative to traditional exclusive sexual relationships.

Hook-ups are sexual encounters ranging from kissing to sexual intercourse. They are often short-lived, nonexclusive, and emotionally shallow, with a purpose of one-time sexual activity (Glenn \& Marquardt, 2001). The terms "friends with benefits" and "casual sex" are also used as synonyms for hooking up (Glenn \& Marquardt, 2001).

\section{Adolescent Sexual Experiences}

Although research has found that most teenagers (roughly 75\%) have their first sexual experience

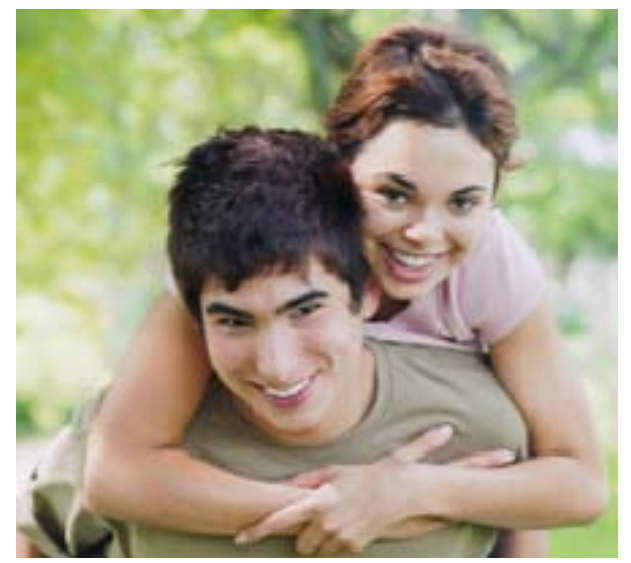

within the context of a dating relationship (Manning, Giordano, \& Longmore, 2005), more than $60 \%$ of sexually active teenagers will eventually have sex with someone they are not dating (Manning, Giordano, \& Longmore, 2006). One study found that approximately $87 \%$ of college students reported hooking up at some point in their lives (Kahn, Fricker, Hoffman, Lambert, Tripp, \& Childress, 2000).

Additionally, more than one-half of the men and one-third of the women in the study reported having intercourse during their hook-up (Lambert, Kahn, \& Apple, 2003).

1. This document is FCS2279, one of a series of the Department of Family, Youth and Community Sciences, Florida Cooperative Extension Service, Institute of Food and Agricultural Sciences, University of Florida. First published October 2007. Please visit the EDIS Web Site at http://edis.ifas.ufl.edu.

2. Christy Daniel, graduate student, and Kate Fogarty, assistant professor, Department of Family, Youth and Community Sciences, Florida Cooperative Extension Service, Institute of Food and Agricultural Sciences, University of Florida, Gainesville, 32611.

The Institute of Food and Agricultural Sciences (IFAS) is an Equal Opportunity Institution authorized to provide research, educational information, and other services only to individuals and institutions that function with non-discrimination with respect to race, creed, color, religion, age, disability, sex, sexual orientation, marital status, national origin, political opinions, or affiliations. U.S. Department of Agriculture, Cooperative Extension Service, University of Florida, IFAS, Florida A\&M University Cooperative Extension Program, and Boards of County Commissioners Cooperating. 


\section{Social Predictors}

Alcohol use or intoxication is generally a precursor to hooking up (Desiderato \& Crawford, 1995). The overwhelming majority of hook-up experiences include alcohol use by both partners (Longmore, Manning, Giordano, \& Rudolph, 2004). Additionally, about half of those who reported hook-ups that included sexual intercourse did not use or were less likely to use a condom (Paul, McManus, \& Hayes, 2000).

\section{Psychological Predictors}

A person's level of self-esteem has been found to be related to whether he or she is likely to "hook up." Most studies have found that men and women with lower self-esteem and/or selfworth hook up more often and have more partners (Longmore et al., 2004; Paul et al., 2000).

Personality can also predict young adults' participation in casual sexual behavior. Unrestrictive or permissive individuals are more likely to seek out sensation and to take more risks. This kind of behavior is strongly associated with many sexual activities, including hooking up (Paul et al., 2000).

\section{The Consequences of Hooking Up}

Various problems can result from hook-ups.

- The dashed hopes and lowered expectations that may result from hook-up relationships can have negative effects on young adults' psychological well-being (Manning et al., 2006).

- Hooking up may keep adolescents and young adults from practicing relationship skills and competencies that can carry forward to more long-term relationships (e.g., marriage) (Manning et al., 2006).

- Hook-ups are often associated with various forms of sexual risk-taking. The results can include sexually transmitted infections
(STIs) and unplanned pregnancy (Manning et al., 2006).

\section{Implications for Adolescents, Young Adults, Parents, and Youth Workers}

Adolescents, young adults and college students need:

- Information concerning the physical and psychological consequences of these risky sexual behaviors.

- Programs that can help them to develop positive relationship skills.

- Activities that encourage relationships with the opposite sex while being centered on building life skills and competencies (e.g., leadership programs and theme clubs).

Parents can deal with the problem of hook-ups in a number of ways.

- Talk with preteens at an early age about sexual behaviors. Many adolescents begin having sex in mid-adolescence. This talk should not simply convey the facts about sexual intercourse, but communicate parental values on the subject. (See EDIS publication FCS2251/FY852, "Communicating with Teens About Sex: Facts, Findings and Suggestions").

- Set rules that guide developmentally appropriate behavior (such as having a curfew for weeknights and weekends when hanging out with friends, and appropriately monitoring the teen's activities).

- Actively monitor the child's social environment (for example, restrict Internet use to common household areas). Such preventative measures will limit the chances that hook-up situations will occur. 


\section{Conclusion}

Alcohol use and low self-esteem can contribute to young adults' hook-up behaviors. Such behaviors have been found to have lasting repercussions on a young person's physical and psychological well-being. Education and community and family support can help protect young people who are at risk of getting involved in early sexual behavior.

\section{References}

Desiderato, L. L., \& Crawford, H. J. (1995). Risky sexual behavior in college students: Relationships between number of sexual partners, disclosure of previous risky behavior, and alcohol use. Journal of Youth \& Adolescence, 24(1), 55-68.

Glenn, N., \& Marquardt, E. (2001). Hooking up, hanging out, and hoping for Mr. Right: College women on dating and mating today. A report conducted by the Institute for American Values for the Independent Women's Forum.

Kahn, A. S., Fricker, K., Hoffman, J., Lambert, T., Tripp, M., \& Childress, K. (2000). Hooking up: Dangerous new dating methods? In A.S. Kahn (Chair), Sex, unwanted sex, and sexual assault on college campuses. Symposium conducted at the annual Meeting of the American Psychological Association, Washington, D.C.

Lambert, T. A., Kahn, A. S., \& Apple, K. J. (2003). Pluralistic ignorance and hooking up. The Journal of Sex Research, 40(2), 129-133.

Longmore, M. A., Manning, W. D., Giordano, P. C., \& Rudolph, J. L. (2004). Self-esteem, depressive symptoms, and adolescents' sexual onset. Social Psychological Quarterly, 67(3), 279-295.

Manning, W. D., Giordano, P. C., \& Longmore, M. A. (2006). Hooking up: The relationship contexts of "non-relationship" sex. Journal of Adolescent Research, 21(5), 459-483.
Manning, W. D., Longmore, M. A., \& Giordano, P. C. (2005). Adolescents' involvement in non-romantic sexual activity. Social Science Research, 34, 384-407.

Paul, E. L., McManus, B., \& Hayes, A. (2000). "Hookups": Characteristics and correlates of college students' spontaneous and anonymous sexual experiences. The Journal of Sex Research, 37(1), 76-88. 